JURNAL HUTAN LESTARI (2019)

Vol. 7 (2) : 893 - 904

\title{
KEANEKARAGAMAN JENIS VEGETASI TEGAKAN HUTAN PADA KAWASAN HUTAN KOTA BUKIT SENJA KECAMATAN SINGKAWANG TENGAH KOTA SINGKAWANG
}

\author{
(Species Diversity Of Forest Vegetation In City Forest Bukit Senja Area Middle Singkawang \\ District Singkawang City)
}

\begin{abstract}
Dwiagustien Putri Melaponty, Fahrizal dan Togar Fernando Manurung Fakultas Kehutanan Universitas Tanjungpura, Jalan Imam Bonjol Pontianak 78124 Email : melaponty96@gmail.com
\end{abstract}

Abstract

The research was conducted in the Bukit Senja City Forest Area, Middle Singkawang District, Singkawang City. The purpose of the research was to find out diversity of forest vegetation in the city forest and vegetation which dominate the forest. The research was carried out for \pm 4 weeks in the field and continued to analysis data. Method used in the research is direct observation through the analysis of vegetation in the field by using a line of paved paths made in a direction perpendicular to the contour with 4 lines each path $=500 \mathrm{~m}$ with lane 1 as many as 25 plots, lane 2 as many as 25 plots, lane 3 as many 19 plots and lanes 4 of 25 plots. Based on analysis on data there were dominant trees which filled the forest based on INP seed, namely Durian $78.828 \%$, Karet $53.480 \%$ and Jelatung $22.81 \%$. According to the type of tillers namely Karet $34.58 \%$, Durian $26.02 \%$, and Simpur $23.97 \%$. From the quantitative analysis it showed that be seen that in the index value dominant $(C)$ of a species is $<1$, which means the kind of go contained in the research is varies not only is controlled by one kind of. Diversity Type $\left(H^{\prime}\right)$ is in the group $<1$ which means it has a moderate Diversity Index $\left(1<H^{\prime}<3\right)$. Abundant index $(e)$ results show that the value of $E=>$ 0.6, which means that the type of abundant is high.

Keywords: Bukit Senja Singkawang middle, City Forest, Vegetation Species Diversity

\section{PENDAHULUAN}

Hutan merupakan sumber daya alam yang tidak terbatas dan mempunyai manfaat yang sangat besar terhadap kehidupan mahluk hidup. Menurut Undang-Undang Pokok Kehutanan No.41 tahun 1999 tentang Kehutanan, hutan merupakan satu kesatuan ekosistem berupa hamparan lahan berisi sumber daya alam hayati yang didominasi pepohonan dalam alam lingkungannya, yang satu dan yang lainnya tidak dapat dipisahkan.
Keanekaragaman jenis vegetasi yang tumbuh dan berkembang disetiap daerah memiliki perbedaan vegetasi tertentu yang di pengaruhi oleh tipe iklim kawasan, tinggi tempat dan faktor lingkungan tumbuhan lainnya. Kalimantan Barat merupakan daerah yang beriklim tropis serta memiliki kekayaan alam hayati dan berbagai flora yang mempunyai nilai tinggi salah satunya adalah tanaman buah-buahan. Keanekaragaman hayati ini merupakan sumber daya hayati yang dapat memberikan 
arti bagi kehidupan apabila dimanfaatkan, selain itu juga dapat mendukung pembangunan pertanian.

Keberadaan hutan kota diatur dalam Peraturan Pemerintah No.63 tahun 2002 tentang Hutan kota. Berdasarkan peraturan tersebut pengertian hutan kota adalah suatu hamparan lahan yang bertumbuhan pohon-pohon yang kompak dan rapat di dalam wilayah perkotaan baik pada tanah negara maupun tanah hak, yang ditetapkan sebagai hutan kota oleh pejabat yang berwenang. Hutan kota Bukit Senja adalah kawasan yang ditutupi pepohonan yang dibiarkan tumbuh secara alami menyerupai hutan, tidak tertata seperti taman, dan lokasinya berada di dalam atau sekitar perkotaan.

Kawasan Hutan Kota Bukit Senja ini lokasinya berada didalam kota dan dipergunakan oleh masyarakat sebagai kawasan wisata maupun tempat Track Jogging. Penelitian ini bertujuan untuk memperoleh keanekaragaman jenis tegakan sehingga masyarakat mengetahui dan memahami betapa pentingnya menjaga kelestarian lingkungan, karena hutan akan mengalami kerusakan yang akhirnya akan mengakibatkan punahnya vegetasi yang ada pada hutan. Manfaat penelitian ini diharapkan dapat dijadikan sebagai bahan acuan dalam kebijakan meningkatkan pengelolaan hutan Kota oleh masyarakat setempat dan tetap menjaga kelestarian Hutan Kota pada Kawasan Bukit Senja
Kecamatan Singkawang Tengah Kota Singkawang.

METODE PENELITIAN

Penelitian ini dilakukan pada kawasan Hutan Kota Bukit Senja Kecamatan Singkawang Tengah Kota Singkawang Provinsi Kalimantan Barat dengan waktu penelitian \pm 4 minggu mulai dari 22 Juli- 20 Agustus 2018 dilapangan dan dilanjutkan dengan pengolahan data. Objek dalam pelaksanaan penelitian ini, yaitu semua jenis tegakan dari tingkat semai, pancang, tiang dan pohon yang terdapat di kawasan Hutan Kota Bukit Senja. Alat-alat yang digunakan dalam penelitian ini berupa peta lokasi penelitian dengan skla 1:25000, GPS dan Kompas, tongkat ukur dan busur untuk mengukur tinggi pohon, ATK, tali raffia, pita ukur $150 \mathrm{~cm}$, parang, dan alat dokumentasi.

\section{Pengumpulan Data}

Data yang dikumpulkan dalam penelitian ini meliputi data primer yaitu jenis dan jumlah tegakan vegetasi tingkat semai serta jenis, jumlah dan diameter untuk tingkat pancang, tiang dan pohon yang ada pada petak pengamatan. Untuk data sekunder meliputi letak dan luas lokasi penelitian, keadaan hutan dan keadaan sosial ekonomi masyarakat.

a. Data primer yang diambil meliputi jenis tumbuhan, jumlah spesies, diameter, dan tinggi pohon. Selanjutnya dilakukan persentase kerapatan, dominansi, frekuensi dan indeks nilai penting. 
Tabel 1.Tallysheet Pengambilan Data Untuk Tingkat Pohon, Tiang, dan Pancang (Thallysheet Of Data Colected for Tree, Pole and Stake).

\begin{tabular}{lllllll}
\hline No Jalur & Petak & Nama lokal Nama jenis & Diameter & $\begin{array}{l}\text { Tinggi } \\
\text { pohon }\end{array}$ & Keterangan \\
\hline 1 & & & & & & \\
2 & & & & & & \\
3 & & & & & & \\
4 & & & & & & \\
\hline
\end{tabular}

Tabel 2. Tallysheet pengambilan Data Untuk Tingkat Semai (Thallysheet Of Data Colected for seedling)

\begin{tabular}{|c|c|c|c|c|c|}
\hline No Jalur & Petak & Nama lokal & Nama jenis & Jumlah & Keterangan \\
\hline \multicolumn{6}{|l|}{1} \\
\hline \multicolumn{6}{|l|}{2} \\
\hline \multicolumn{6}{|l|}{3} \\
\hline 4 & & & & & \\
\hline
\end{tabular}

b. Data Sekunder

Data sekunder diperoleh dari berbagai sumber yang meliputi tentang data keadaan umum lokasi penelitian diantaranya luas, dan letak wilayah, topografi, geologi dan tanah, iklim vegetasi, dan sosial ekonomi masyarakat serta literatur yang menunjang penelitian.

\section{Pelaksanaan Penelitian}

Luas areal penelitian $4 \mathrm{Ha}$ dengan jumlah 20 petak, dimana dibuat beberapa tingkatan yaitu $20 \times 20$ m untuk tingkat pohon, $10 \mathrm{x} 10 \mathrm{~m}$ untuk tingkat tiang, $5 \mathrm{x}$ $5 \mathrm{~m}$ untuk tingkat pancang, dan $2 \times 2 \mathrm{~m}$ untuk tingkat semai. Penelitian ini menggunakan metode observasi langsung melalui analisis vegetasi di lapangan dengan menggunakan garis berpetak, jalur rintis dibuat dengan arah tegak lurus kontur. Yang dapat dilihat pada jalur pengamatan dibawah ini :

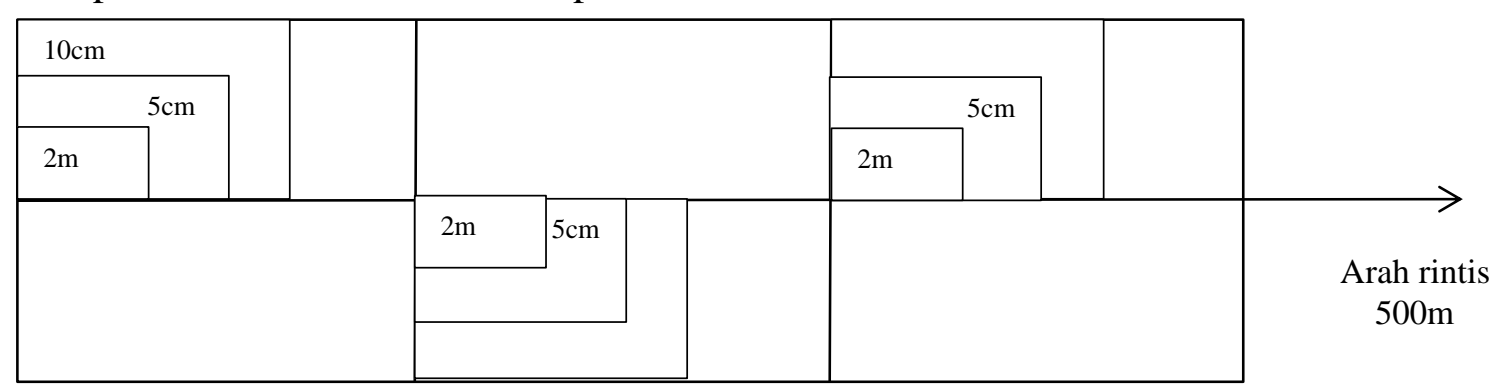

Gambar 1. Jalur Pengamatan Pada Lokasi Penelitian (Observations Track on Research Locations) 


\section{Analisis Vegetasi}

Analisis vegetasi adalah cara untuk mempelajari komposisi jenis dan struktur vegetasi di dalam suatu ekosistem. Dalam analisis vegetasi dilakukan penghitungan Indeks Nilai Penting, Indeks Dominasi (C), Indeks keanekaragaman jenis $(\mathrm{H})$, dan Indeks Kelimpahan Jenis (e). INP merupakan penjumlahan dari kerapatan relatif (KR), frekwensi relatif (FR), dan dominansi relatif (DR). Rumus yang digunakan adalah sebagai berikut:

a. Indeks Nilai Penting (INP)

Indeks Nilai Penting digunakan untuk menentukan dominasi suatu jenis terhadap jenis lainnya dalam suatu tegakan (Ferianita, 2006). Untuk tingkat tiang dan pohon nilai INPnya $\geq 15 \%$, sedangkan untuk pancang dan semai nilai INPnya $\geq$ $10 \%$. Dengan rumus sebagai berikut : INP tingkat semai dengan rumus :

$$
\mathrm{INP}=\mathrm{KR}+\mathrm{FR}
$$

INP tingkat Pancang, tiang dan pohon, dengan rumus :

$$
\mathrm{INP}=\mathrm{KR}+\mathrm{FR}+\mathrm{DR}
$$

Dimana :

$$
\begin{aligned}
& \mathrm{KR}=\text { Kerapatan Relatif } \\
& \mathrm{FR}=\text { Frekuensi Relatif } \\
& \mathrm{DR}=\text { Dominansi Relatif }
\end{aligned}
$$

b. Indeks Dominasi (C)

Indeks Dominasi (C) Indeks dominasi digunakan untuk menetukan dominasi dalam suatu komunitas dan tingkat perkembangan permudaan. Dengan rumus sebagai berikut (Odum, 1993):

$$
\mathrm{C}=\sum\left[\frac{n i(n i-1)}{\mathrm{N}(\mathrm{N}-1)}\right]
$$

Dimana :

$$
\begin{aligned}
& \mathrm{C}=\text { indeks dominasi } \\
& \text { ni = Jumlah individu dari spesies } \\
& \text { ke } \mathrm{i} \\
& \mathrm{N}=\text { jumlh individu dari semua } \\
& \text { jenis }
\end{aligned}
$$

c. Indeks Keanekaragaman Jenis (H')

Simpson (1949) menyatakan bahwa tidak hanya jumlah spesies dan jumlah total individu dalam masing-masing ikut menentukan. Kumpulan spesies dengan keanekaragaman tinggi akan mempunyai dominasi rendah, sehingga indeks keanekaragaman dihitung dengan rumus sebagai berikut:

$$
H=-\sum\left\{\left(n_{i} / N\right) \log \left(n_{i} / N\right)\right\}
$$

Keterangan:

$\mathrm{H}=$ indeks keanekaragaman Shannon

$\mathrm{n}_{\mathrm{i}}=$ Nilai penting dari tiap spesies

$\mathrm{N}=$ Total nilai penting

d. Indeks Kelimpahan Jenis (e)

Indeks kelimpahan jenis dipengaruhi oleh keanekaragaaman jenis dan jumlah jenis yang digunakan untuk mengetahui kelimpahan suatu jenis di suatu area atau suatu ukuran contoh tertentu. Untuk itu digunakan rumus Odum, 1993.

$$
\mathrm{e}=\mathrm{H} /(\log \mathrm{S})
$$

keterangan :

$\mathrm{e}=$ kelimpahan jenis

$\mathrm{H}=$ keanekaragaman jenis

$\mathrm{S}=$ jumlah dari jenis

\section{HASIL DAN PEMBAHASAN}

Penelitian dilaksanakan di Hutan Kota Bukit Senja Singkawang Tengah Kota Singkawang waktu penelitian selama 4 minggu di hitung dari 22 Juli 
JURNAL HUTAN LESTARI (2019)

Vol. 7 (2) : 893 - 904

sampai dengan 20 Agustus 2018. Luas areal Penelitian 4 Ha dengan jumlah 94 petak dengan 4 jalur, dimana dibuat beberapa tingkatan yaitu $20 \times 20 \mathrm{~m}$ untuk tingkat pohon, $10 \times 10 \mathrm{~m}$ untuk tingkat tiang, $5 \times 5 \mathrm{~m}$ untuk tingkat pancang, dan $2 \times 2 \mathrm{~m}$ untuk tingkat semai.

Tabel 3. Jumlah Jenis Dan Individu Yang Terdapat Dalam Jalur Pengamatan Untuk Semua Jalur (Total Number of Species and individuals were found at all observation Track).

\begin{tabular}{|c|c|c|c|}
\hline No & Tingkat Pertumbuhan & Jumlah Jenis & Jumlah Individu/Ha \\
\hline 1 & 2 & 3 & 4 \\
\hline 1 & Semai & 26 & 584 \\
\hline 2 & Pancang & 29 & 380 \\
\hline 3 & Tiang & 31 & 300 \\
\hline 4 & Pohon & 30 & 218 \\
\hline & Total & & 1482 \\
\hline
\end{tabular}

Sumber : Analisis Data 2018

Berdasarkan hasil penelitian yang di lakukan, di temukan 35 spesies untuk tingkat pertumbuhan dan di semua kawasan yang di teliti. Hasil analisis vegetasi di Bukit Senja kecamatan Singkawang Tengah untuk masingmasing tingkat pertumbuhan vegetasi tingkat semai ditemukan sebanyak 26 jenis dan 584 jumlah individu dengan 25 petak perpanjang jalur $500 \mathrm{~m}$, tingkat pancang ditemukan sebanyak 29 jenis dan 380 jumlah individu dengan 25 petak perpanjang jalur $500 \mathrm{~m}$, tingkat tiang ditemukan sebanyak 31 jenis dan 300 jumlah individu dengan 19 petak perpanjang jalur $500 \mathrm{~m}$, pada jalur 3 dibuat hanya 19 petak di karenakan kondisi lapangan yang tidak memungkinkan untuk dilewati, dan tingkat pohon ditemukan sebanyak 30 jenis dan 218 jumlah individu dengan 25 petak perpanjang jalur $500 \mathrm{~m}$. Dapat dilihat pada Tabel 3 .

\section{Indeks Nilai Penting}

Berdasarkan data hasil penelitian diketahui beberapa janis vegetasi dari tingkat semai sampai dengan tingkat pohon yang merupakan jenis dominan, yaitu jenis yang memiliki indeks nilai penting yang tinggi. Indeks Nilai Penting (INP) yang didapat melalui akumulasi nilai kerapatan Relatif (KR), Frekuensi Relatif (FR) dan Dominansi Relatif (DR). Sedangkan pada vegetasi tingkat semai dan tumbuhan bawah didapat dari penjumlahan nilai Kerapatan Relatif (KR), dan Frekuensi Relatife (FR). Analisis tumbuhan merupakan suatu cara mempelajari susunan atau komposisi jenis dan bentuk atau struktur vegetasi. 
Tabel 4. Nilai INP di setiap Tingkat Pertumbuhan di Kawasan Bukit Senja Kecamatan Singkawang Tengah Kota Singkawang (Important Value Index At Each Growth Level In Bukit Senja Area Middle Singkawang District, Singkawang City).

\begin{tabular}{|c|c|c|c|c|c|c|}
\hline \multirow[b]{2}{*}{ No } & \multirow{2}{*}{ Spesies } & \multirow{2}{*}{ Family } & \multicolumn{4}{|c|}{ Indeks Nilai Penting } \\
\hline & & & Pohon & Tiang & Pancang & Semai \\
\hline 1 & Albizzia falcataria & Fabaceae & 3,989 & 3,78 & & \\
\hline 2 & Aleurites moluccana & Euphorbiaceae & 6,275 & 18,82 & 11,35 & 0,34 \\
\hline 3 & Alstonia sp & Apocynaceae & 5,820 & 2,29 & 1,76 & 4,79 \\
\hline 4 & Antidesma neurocarpum & Phyllanthaceae & 4,359 & & 7,38 & 7,87 \\
\hline 5 & Archidendron pauciflorum & Fabaceae & 15,299 & 16,87 & 13,12 & 1,36 \\
\hline 6 & Artocarpus heterophyllus & Moraceae & & 3,10 & 4,19 & 5,13 \\
\hline 7 & Artocarpus integer & Moraceae & 4,148 & 10,47 & 0,72 & \\
\hline 8 & Artocarpus odoratissimus & Moraceae & 19,715 & 15,68 & 17,14 & 3,08 \\
\hline 9 & Averrhoa bilimbi & Oxalidaceae & 1,304 & 0,81 & & \\
\hline 10 & Averrhoa carambola & Oxalidaceae & 2,523 & 12,31 & & \\
\hline 11 & Baccaurea motleyana & Phyllanthaceae & 7,594 & 1,57 & 9,52 & 1,36 \\
\hline 12 & Calophyllum & Clusiaceae & & 0,80 & 8,00 & 14,04 \\
\hline 13 & Cratoxylon arborescens & Clusiaceae & 2,532 & 2,40 & 1,88 & 5,82 \\
\hline 14 & Dialium sp & Caesalpiniaceae & 4,542 & 7,61 & 12,78 & 2,05 \\
\hline 15 & Dillenia Suffruticosa & Dilleniaceae & & 7,61 & 25,57 & 23,97 \\
\hline 16 & Durio zibethinus & Malvaceae & 78,828 & 49,61 & 36,16 & 26,02 \\
\hline 17 & Dyera lowii & Apocynaceae & 22,891 & 16,34 & 5,49 & 1,02 \\
\hline 18 & Elateriospermum topas $B I$ & Euphorbiaceae & 1,219 & 2,28 & 1,44 & \\
\hline 19 & Gluta spp & Anacardiaceae & 5,550 & 10,67 & 24,91 & 1,36 \\
\hline 20 & Gossypium arboreum & Malvaceae & 3,734 & 11,04 & 2,55 & 3,76 \\
\hline 21 & Hevea brasiliensis & Euphorbiaceae & 53,480 & 36,39 & 44,80 & 34,58 \\
\hline 22 & Lansium domesticum & Meliaceae & 2,573 & 12,25 & 7,70 & 2,73 \\
\hline 23 & Leucaena leucocephala & Fabaceae & 1,585 & 12,43 & 3,21 & \\
\hline 24 & Macaranga triloba & Euphorbiaceae & & 1,57 & 0,73 & 9,58 \\
\hline 25 & Mangifera Indica & Anacardiaceae & 13,975 & 8,20 & 12,55 & 20,89 \\
\hline 26 & Nauclea subdita & Rubiaceae & 4,641 & 2,32 & 3,52 & 5,82 \\
\hline 27 & Nephelium lappaceum L & Sapindaceae & 3,974 & 12,64 & 8,78 & 11,64 \\
\hline 28 & Palaquium sp & Sapotaceae & 2,064 & 1,53 & 1,02 & \\
\hline 29 & Polyalthia lateriflora & Annonceae & 5,150 & 2,69 & 15,17 & 1,02 \\
\hline 30 & Pometia pinnata & Sapindaceae & 6,068 & 9,01 & 1,48 & 0,68 \\
\hline 31 & Prunus arborea & Rosaceae & 1,244 & & 2,04 & 4,45 \\
\hline 32 & Psidium Guajava & Myrtaceae & & 0,81 & & \\
\hline 33 & Terminalia catappa & Combretaceae & 4,793 & & & 0,34 \\
\hline 34 & Theobroma cacao & Malvaceae & 1,219 & 0,85 & & \\
\hline 35 & Urophyllum arboreum & Rubiaceae & 8,912 & 12,72 & 14,92 & 6,16 \\
\hline
\end{tabular}

Sumber : Analisis Data 2018. 
Berdasarkan hasil analisis data diperoleh jenis yang dominan berdasarkan INP pada tingkat semai terdapat jenis karet $34,58 \%$, Durian 26,02\% dan Simpur 23,97\%. Sedangkan untuk tingkat pancang nilai INP tertinggi terdapat pada jenis karet $44,80 \%$ Durian $36,16 \%$ dan Simpur 25,57\%. Untuk tingkat tiang nilai INP tertinggi Durian 49,61\%, Karet 36,39\% dan Kemiri $18,82 \%$.untuk tingkat pohon nilai INP tertinggi terdapat jenis Durian $78,82 \%$, karet $53,48 \%$ dan Jelatung $22,89 \%$. Nilai Indeks Penting (INP) yang terdapat pada tingkat semai sampai tingkat pohon yang mendominasi terdapat tanaman buah, tanaman kayu bangunan serta tanaman komoditi, yang pada dasarnya hutan kota ini merupakan hutan alam.

Secara keseluruhan jenis yang termasuk paling besar nilai INP nya adalah Hevea brasiliensis dan Durio zibethinus. Penelitian ini Durio zibethinus termasuk yang memiliki INP tinggi dikarenakan tingkat kesesuaian tempat tumbuh atau adaptasi yang baik dan memiliki indukan yang membuat pohon tersebut dominan, masyarakat dapat memperbanyak dengan biji dilakukan untuk memperoleh batang bawah, maupun dengan cara pencangkokan ditambah lagi daerah yang memungkinkan untuk tumbuh Pohon Durian sehingga Pohon Durian ini menjadi dominan di daerah Bukit Senja.
Vegetasi selain Hevea brasiliensis dan Durio zibethinus juga terdapat nilai INP tertinggi antara lain Dyera lowii, Dillenia Suffruticosa ,dan Gluta spp. Ini di karenakan tingkat kesesuaian terhadap tempat tumbuh atau adaptasi yang lebih baik dibandingkan dengan jenis lainnya dan terdapat pohon induk yang membuat pohon tersebut lebih dominan diantara pohon lainnya.

Menurut Soegianto,

mengatakan bahwa Indeks Nilai Penting (INP) digunakan untuk menggambarkan tingkat penguasaan yang diberikan oleh suatu spesies terhadap komunitas, semakin besar Nilai INP suatu spesies semakin besar tingkat penguasaan terhadap komunitas dan sebaliknya. Beragamnya nilai INP menunjukkan adanya pengaruh lingkungan tempat tumbuh seperti kelembaban, suhu dan tidak mampu atau kalah berkompetisi, seperti perebutan akan zat hara, sinar matahari dan ruang tumbuh dengan jenisjenis lainnya yang sangat mempengaruhi pertumbuhan dari diameter batang pohon. Menurut Odum (1971), jenis yang dominan mempunyai produktivitas yang besar, dan dalam menentukan suatu jenis vegetasi dominan yang perlu diketahui adalah diameter batangnya. Keberadaan jenis dominan pada lokasi penelitian menjadi suatu indikator bahwa komunitas tersebut berada pada habitat yang sesuai dan mendukung pertumbuhannya. 
JURNAL HUTAN LESTARI (2019)

Vol. 7 (2) : 893 - 904

Indeks Dominasi (C), Indeks Keanekaragaman Jenis (H') dan Indeks Kelimpahan Jenis (E).

Tabel 5. Indeks Dominansi (C), Indeks Keanekargaman Jenis (H), Indeks Kelimpahan Jenis (E) Vegetasi Penyusun Hutan di Kawasan Bukit Senja Kecamatan Singkawang Tengah Kota Singkawang (Dominance Index $(C)$, Species Diversity Index (H'), Abundance Index (E) of Vegetation Forest City Bukit Senja Area Middle Singkawang District, Singkawang City).

\begin{tabular}{clccc}
\hline No & $\begin{array}{c}\text { Tingkat } \\
\text { Pertumbuhan }\end{array}$ & $\begin{array}{c}\text { Indeks Dominansi } \\
(\mathrm{C})\end{array}$ & $\begin{array}{c}\text { Indek Keanekaragaman } \\
\text { Jenisi (H') }\end{array}$ & $\begin{array}{c}\text { Indeks Kelimpahan } \\
\text { Jenis (E) }\end{array}$ \\
\hline 1 & Semai & 0,8976 & 1,176173 & 0,831233 \\
2 & Pancang & 0,07111 & 1,256808 & 0,859416 \\
3 & Tiang & 0,070354 & 1,313812 & 0,880948 \\
4 & Pohon & 0,1211 & 0,9658 & 0,6538 \\
\hline
\end{tabular}

Sumber : Analisis Data 2018

a. Indek Dominasi (C) jenis vegetasi tegakan pada kawasan Hutan Kota Bukit Senja Kecamatan Singkawang Tengah Kota Singkawang.

Terhadap nilai Indeks Nilai Penting (INP) dari masing-masing jenis yang ada, jenis yang dikategorikan sebagai jenis yang dominan adalah jenis yang memiliki nilai INP yang tertinggi. Dikemukakan oleh Soerianegara dan Indrawan (1998) bahwa jenis yang memiliki peran dan mendominasi suatu habitat pada suatu komunitas adalah jenis yang memiliki Indek Nilai Pening (INP) yang tinggi. Berdasarkan hasil analisa data bahwa pada keseluruhan jalur pengamatan Nilai Indek Dominasi (C) dari suatu jenis adalah $<1$, artinya jenis tegakan yang terdapat dalam lokasi penelitian adalah bervariasi atau pada komunitas tersebut dominasi jenisnya tidak hanya dikuasai satu jenis saja tetapi masih terdapat beberapa jenis lain yang mendominasi daerah tersebut.
Berdasarkan hasil analisa indeks dominasi pada Tabel 5, untuk tingkat semai sebesar $\mathrm{C}=0,8976$, untuk tingkat pancang $\mathrm{C}=0,07111$, untuk tingkat tiang sebesar $\mathrm{C}=0,070354$, dan untuk tingkat pohon $\mathrm{C}=0,1211$. Dari hasil tersebut nilai Indeks Dominasi (C) sudah masuk dari nilai 1 untuk semua tingkat pertumbuhan, hal ini menunjukkan bahwa sudah terdapat jenis yang mendominasi jenis lainnya. Indeks Dominansi (C) menggambarkan pola pemusatan dan penyebaran jenis dalam tegakan. Indeks dominasi merupakan kebalikan dari indeks keanekaragaman jenis, karena pola pemusatan terjadi lebih baik pada keanekaragaman yang rendah. Dilihat semua tingkat pertumbuhan dari tingkat semai sampai tingkat pohon berarti tidak terdapat spesies yang mendominansi spesies yang lainnya atau struktur komunitas dalam keadaan stabil karena $\mathrm{C}=0$. 
Menurut Odum (1993), menyatakan bahwa kebanyakan komunitas alam mengandung sedikit jenis dengan jumlah individu yang besar (jenis umum atau dominan) dan sebaliknya banyak jenis masing-masing mewakili oleh sedikit individu (jenis yang jarang) dengan jumlah sedikit maka pengusahaan pada tempat tumbuhnya semakin besar, dengan demikian pemusatan jenis-jenis dominan akan tersebar dengan merata, karena dengan sedikitnya jenis memungkinkan jumlah individu yang tumbuh dan berkembang lebih baik.

b. Indeks Keanekaragaman jenis vegetasi di Hutan Kota Bukit Senja Kecamatan Singkawang Tengah Kota SIngkawang.

Indek Keanekaragaman jenis untuk tingkat semai sebesar 1,176173, untuk tingkat pancang sebesar 1,256808 , untuk tingkat tiang sebesar 1,313812, dan untuk tingkat pohon 0,9658. Hasil analisa menunjukkan bahwa di sekitar Bukit Senja memiliki Indek Keanekaragaman jenis termasuk dalam kategori rendah $\left(1<\mathrm{H}^{\prime}<3\right)$, karena menunjukkan bahwa kawasan ini masih memiliki ciri hutan hujan tropika, hal tersebut sesuai dengan pendapat Richard (1979) yang menyatakan bahwa hutan yang dijumpai di Philipina, Malaysia, dan Indonesia senantiasa hijau dan kaya akan jenis tumbuhan, berbeda dengan Afrika yang kekayaan hutan Relative miskin dan seragam. Namun bila dilihat dari perubahan nilai indeks keanekargaman mulai dari semai sampai tingkat pohon terlihat adanya cenderung menurun. Hal ini mengambarkan bahwa telah terjadinnya suksesi sehinga ada jenisjenis tingkat bawah yang tidak mampu bertahan sampai ke pohon. Menurut Simpsom (1994), menyatakan bahwa tidak hanya jumlah spesies dan jumlah individu, akan tetapi proporsi dari jumlah individu dalam masing-masing spesies ikut menentukan.

Berdasarkan Indeks keragaman jenis pada jalur pengamatan keanekaragaman jenis pada jalur pengamatan antara (0,9658-1,3138), Keanekaragaman jenis yang semakin tinggi dalam suatu komunitas menunjukkan bahwa semakin tinggi kemampuan jenis yang lain untuk tumbuh dan berkembang pada kawasann tersebut. Hal ini disebabkan vegetasi hutan yang tumbuh beranekaragam dan jumlah individu masing-masing jenis yang tinggi. Yang memungkinkan jenis tumbuhan tertentu untuk tumbuh dengan baik. Dan intesitas cahaya yang terdapat pada kawasan tersebut lebih normal, untuk tumbuh dan berkembang. Keanekaragaman jenis yang terjadi pada masing-masing tingkat pertumbuhan disebabkan karena adanya perubahan vegetasi yang terjadi secara terus menerus dan ditunjung oleh keberadaan unsur hara, air, mineral dan cahaya yang diperoleh oleh vegetasi. Dengan adanya kebutuhan yang sama terhadap zat-zat tersebut maka menyebabkan terjadinya masyarakat tumbuh-tumbuhan yang 
meliputi bentuk, macam, dan banyaknya jenis serta dalam individu sesuai dengan tempat tumbuhnya (Soerianegara dan Indrawan, 1988).

Suatu komunitas tersebut dinyatakan memiliki keanekaragaman spesies yang tinggi jika komunitas tersebut disusun oleh banyak spesies. Sebaliknya suatu komunitas dinyatakan rendah apabila komunitas tersebut disusun oleh spesien yang sedikit dan hanya ada sedikit spesies yang dominan (Indriyanto,2006).

Berdasarkan penjelasan diatas dapat disimpulakan bahwa keanekaragaman jenis adalah jumlah total spesies yang bermacam-macam yang menempati suatu lokasi tertentu.

c. Indeks Kelimpahan jenis vegetasi Pada Kawasan Hutan Kota Bukit Senja Kecamatan Singkawang Tengah Kota Singkawang Provinsi Kalimantan Barat.

Indeks kelimpahan jenis (E) adalah indeks yang digunkan untuk mengetahui kelimpahan suatu jenis. Indeks kelimpahan jenis sangat dipengaruhi oleh nilai keanekargaman jenis. Dari tebel menunjukan bahwa indeks kelimpahan jenis tertinggi berada pada tiangkat semai sebesar 0,831233 , untuk tingkat pancang 0,859416, untuk tingkat Tiang sebesar 0,880948, dan untuk tingkat pohon 0,6538 . Hal ini menujukan bahwa indeks kelimpahan jenis pada semua tingkat pengamatan dalam kategori sedang atau cukup melimpah.
Kelimpahan suatu spesies adalah banyaknya individu dari suatu spesies yang menempati area tertentu yang dapat dipengaruhi oleh faktor lingkungan. Hasil perhitungan menunjukkan bahwa nilai $\mathrm{E}$ pada setiap tingkat pertumbuhan pada berbagai petak pengamatan memiliki nilai yang tergolong sedang dan tinggi, karena Kelimpahan jenis bedasarkan ketentuan Magguran (1988) apabila kelimpahan $(\mathrm{E} \leq 0,3)$ menujukan kelimpahan jenis rendah, 0,3-0,6 menujukan kelimpahan jenis tergolong sedang dan jika $E=\geq 0,6$ kelimpahn jenis tergolong tinggi. Berdasarkan pengertian tersebut dapat disimpulkan bahwa, kelimpahan suatu spesies adalah banyaknya individu dari suatu spesies yang menempati area atau wilayah tertentu. Kelimpahan suatu spesies dalam area tertentu juga dapat dipengaruhi oleh faktor lingkungan.

\section{Kesimpulan}

Berdasarkan hasil penelitian dan pembahasan, yang dilakukan pada kawasan Bukit Senja Kecamatan Singkawang Tengah Kota Singkawang maka dapat diambil beberapa kesimpulan sebagai berikut :

1. Jumlah keseluruhan vegetasi ditemukan di kawasan Bukit Senja yang terdapat dalam petak pengamatan untuk tingkat semai sebanyak 26 jenis, untuk tingkat pancang 29 jenis, untuk tingkat tiang 31 jenis dan tingkat pohon sebanyak 30 jenis. Sedangkaan untuk pohon yang mendominasi dan 
dikenal masyarakat adalah Durio zibethinus dan Hevea brasiliensis.

2. Indeks Nilai Penting keseluruhan vegetasi pada tingkat semai nilai INP tertinggi terdapat pada Durio zibethinus $78,828 \%$ pada tingkatan pohon, pada tingkatan tiang terdapat Durio zibethius $49,61 \%$, untuk tingkat pancang terdapat Hevea brasiliensis $44,80 \%$ dan pada tingkatan semai Havea brasiliensis $34,58 \%$.

3. Nilai Indek Dominasi (C) untuk keseluruhan vegetasi tertinggi yaitu pada tingkat semai, yaitu $0,8976 \%$ dan pada tingkatan pohon $0,1211 \%$. Hal ini menggambarkan bahwa terdapat jenis yang mendominasi jenis lain atau bervariasi.

4. Nilai Indek Keanekaragaman Jenis untuk keseluruhan vegetasi untuk tingkat semai $1,1761 \%$, pada tingkat pancang $1,2568 \%$, pada tingkat tiang $1,3138 \%$, dan pada tingkat pohon $0,9658 \%$. Hal ini menunjukkan bahwa kanekaragaman jenis tergolong cukup tinggi karena $\left(1>\mathrm{H}^{\circ}<3\right)$.

5. Indeks Kesamaan Komunitas untuk keseluruhan vegetasi dan pohon hutan pada tingkat semai, pancang, tiang, dan pohon tergolong tinggi. Hal ini menggambarkan bahwa komunitas vegetasi yang terdapat pada kawasan Hutan Kota Bukit Senja hampir sama (mendekati 100\%).

\section{Saran}

Perlu adanya upaya menjaga dan mempertahankan keberadaan kawansan
Hutan Kota Bukit Senja, untuk dapat di kelola dalam kebijakan peningkatan pengelolaan hutan pada masa mendatang. Juga upaya konservatif secara terencana dan terarah melalui pengkayaan jenis terhadap kawasan yang dirasa kurang permudaannya. Pengkayaan jenis dilakukan terutama dari jenis-jenis asli setempat, dan jenis-jenis bermanfaat, misalnya dari jenis buah-buahan dan jenis lainnya sehingga tetap terjaganya keadaan ekosistem yang baik sebagai sumber plasma nutfah.

\section{DAFTAR PUSTAKA}

Ferianita, M. 2006. Metode Sampling Bioekologi. Bumi Aksara. Jakarta.

Indriyanto, 2006. Ekologi Hutan. Jakarta : Bumi Aksara. 2006.

Magguran, 1988. Keanekaragaman dan Pengukurannya.

PrincetonUniversity press.

Odum, E.P. 1971. Dasar-dasar Ekologi. Gadjahmada University Press. Yogyakarta.

Odum, E.P. 1993. Dasar-dasar Ekologi. Penerjemah Tjahjono Samingan ; Penyunting B. Srigandono. Yogyakarta : Gadjahmada University Press. 1993.

Peraturan Pemerintah (PP) No.63. Tahun 2002.

Richard, P.W. 1979. The Tropical Rain Forest: an Ecological Study. Yayasan Pembina Fakultas Kehutanan UGM. Yogyakarta.

Simpson, E. H. 1994. Catatan Polusi Undara Pada Divisi Kuliah Ilmu 
JURNAL HUTAN LESTARI (2019)

Vol. 7 (2) : 893 - 904

Lingkungan. Grifith University. Queensland.

Soegianto, 1994. Ekologi Kuantitatif. Usaha Nasional, Surabaya.

Soerianegara, I dan A. Indrawan, 1988. Ekologi Hutan Indonesia. Fakultan Kehutanan IPB. Bogor.
Soerianegara, I dan A. Indrawan, 1998. Ekologi Hutan Indonesia. Buku Laboratorium Ekologi Hutan. Fakultas Kehutanan IPB. Bogor.

Undang-undang No. 41. 1999. Ketentuan Pokok Kehutanan. Jakarta. 